\begin{tabular}{|c|c|}
\hline \multirow[b]{2}{*}{ ikan } & $\begin{array}{l}\text { Jurnal Penelitian dan Evaluasi Pendidikan } \\
\text { Volume 20, No 2, Desember } 2016 \text { (142-155) }\end{array}$ \\
\hline & Online: http://journal.uny.ac.id/index.php/jpep \\
\hline
\end{tabular}

\title{
KEMAMPUAN BERPIKIR TINGKAT TINGGI SISWA SMP DI KABUPATEN JEMBER DALAM MENYELESAIKAN SOAL BERSTANDAR PISA
}

\author{
Dian Kurniati ${ }^{1}{ }^{*}$, Romi Harimukti ${ }^{1}$, Nur Asiyah Jamil ${ }^{1}$ \\ ${ }^{1}$ Pendidikan Matematika Fakultas Keguruan dan Ilmu Pendidikan Universitas Jember \\ 1Jl. Kalimantan No. 37, Krajan Timur, Sumbersari, Jember, Jawa Timur 68121, Indonesia \\ * Corresponding Author. Email: dian.kurniati@unej.ac.id
}

\begin{abstract}
Abstrak
Tujuan penelitian ini adalah mendeskripsikan kemampuan berpikir tingkat tinggi (Higher Order Thinking Skills/HOTS) siswa dalam menyelesaikan soal PISA berdasarkan indikator yang telah disusun. Kemampuan berpikir tingkat tinggi dalam penelitian ini meliputi kemampuan logika dan penalaran, analisis, evaluasi, serta kreasi. Penelitian ini merupakan penelitian deskriptif dengan pendekatan kualitatif. Metode pengumpulan data meliputi metode dokumentasi, tes, dan wawancara. Hasil penelitian dari 30 siswa yang tersebar di beberapa SMP di Kabupaten Jember didapatkan bahwa 18 siswa mampu melakukan kemampuan logika dan penalaran, analisis, evaluasi, serta kreasi dengan baik dalam menyelesaikan beberapa soal, sehingga tergolong memiliki kemampuan berpikir tingkat tinggi dengan level sedang. Selanjutnya, 12 siswa tidak mampu melakukan kemampuan analisis, evaluasi, kreasi, logika dan penalaran dengan baik dalam menyelesaikan semua soal, sehingga tergolong memiliki kemampuan berpikir tingkat tinggi dengan level rendah.
\end{abstract}

Kata kunci: PIS A, kemampuan logika dan penalaran, kemampuan analisis, evaluasi, kreasi

\section{THE HIGHER ORDER THINKING SKILLS OF JUNIOR HIGH SCHOOL STUDENTS AT JEMBER DISTRICT IN SOLVING PISA STANDAR-BASED TEST ITEM}

\begin{abstract}
The purpose of this research was to describe the higher order thinking skills of students in solving PISA standar-based test item based on indicators that had been compiled. The indicators in this research were the ability of logic and reasoning, analysis, evaluation, and creation. This research is a descriptive qualitative approach. The data collection methods in this research were documentation, test, and interview. From 30 students spread across many Junior High Scoolls in Jember district, 18 students are found to be able to perform logic skills and reasoning, analysis, evaluation, and creation well in resolving some of the problems, thus classified as having high level thinking skills with moderate level. Furthermore, 12 students are not able to perform analytical skills, evaluation, creation, logic and reasoning well in solving all the problems, so they are considered to have low level high order thinking skill.
\end{abstract}

Keywords: PIS A, logic and reasoning, analysis, evaluation, creation skills

Permalink/DOI: bttp:/ / dx.doi.org/10.21831/pep.v20i2.8058 


\section{Pendahuluan}

Pada era globalisasi dan tuntutan Masyarakat Ekonomi Asean (MEA) memerlukan sumber daya manusia (SDM) yang berkualitas. Salah satu faktor yang memengaruhi kualitas SDM ialah pendidikan. Kualitas pendidikan dimulai dari peningkatan kualitas pembelajaran. Peningkatkan kualitas pembelajaran dapat dimulai dengan menyusun tujuan pembelajaran yang tepat (Istiyono, Mardapi, \& Suparno, 2014).

SDM yang berkualitas memiliki pemikiran kritis, sistematis, logis, kreatif, dan kemauan untuk bekerja sama secara efektif. Sumber daya manusia yang memiliki pemikiran seperti yang telah disebutkan, dihasilkan dari lembaga pendidikan sekolah. Salah satu bidang ilmu yang sangat berperan dalam dunia pendidikan adalah matematika.

Pemahaman matematika merupakan pusat kesiapan generasi muda untuk hidup dalam masyarakat modern. Sebuah proporsi pertumbuhan masalah dan situasi yang dihadapi dalam kehidupan sehari-hari, termasuk dalam konteks profesional, memerlukan beberapa tingkat pemahaman matematika, penalaran matematika dan alat-alat matematika. Matematika adalah alat penting untuk generasi muda karena mereka menghadapi masalah dan tantangan dalam aspek pribadi, pekerjaan, sosial, dan ilmiah kehidupan mereka. Dengan demikian, penting untuk memiliki pemahaman tentang sejauh mana peserta didik yang cukup siap untuk menerapkan matematika dalam memecahkan masalah (OECD, 2013, p. 24).

Keterlibatan Indonesia dalam Programme for International Student Assessment (PISA) adalah dalam upaya melihat sejauh mana program pendidikan di negara kita berkembang dibanding negara-negara lain di dunia. PISA merupakan suatu studi bertaraf internasional yang diselenggarakan oleh $\mathrm{Or}$ ganization for Economic Cooperation and Development (OECD) yang mengkaji kemampuan berpikir siswa pada rentang usia 15 tahun yang diikuti oleh beberapa negara peserta, termasuk Indonesia. Program ini dikembangkan untuk mengukur apakah siswa pada usia tersebut telah menguapsai apa yang se- harusnya mampu dicapai, serta untuk mengetahui apakah siswa mampu mengaplikasikan pengetahuaan mereka dalam kehidupan sehari-hari.

Soal-soal PISA bukan hanya menuntut kemampuan dalam penerapan konsep saja, tetapi lebih kepada bagaimana konsep itu dapat diterapkan dalam berbagai macam situasi. Wardhani (2015) mengemukakan bahwa soal PISA menuntut kemampuan penalaran dan pemecahan masalah. Selanjutnya Setiawan (2014) mengemukakan soal PISA selain menuntut kemampuan penalaran juga menuntut kemampuan analisis, evaluasi, dan kreasi dalam pengerjaannya.

Berdasarkan hasil survei PISA tahun 2012 Indonesia hanya sedikit lebih baik dari Peru yang berada di ranking terbawah. Ratarata skor matematika anak-anak Indonesia 375. Indonesia hanya menduduki rangking 64 dari 65 negara dengan rata-rata skor 375 , sementara rata-rata skor internasional adalah 500 (OECD, 2014, p. 5). Hal ini menunjukkan kemampuan siswa Indonesia dalam menyelesaikan soal-soal yang menuntut kemampuan analisis, evaluasi, kreasi, serta logika dan penalaran sangat kurang.

Pohl (Lewy, Zulkardi, \& Aisyah, 2009) menyatakan bahwa kemampuan melibatkan analisis, evaluasi, dan kreasi dianggap sebagai kemampuan berpikir tingkat tinggi. Menurut Brookhart (2010, p. 29) kemampuan berpikir tingkat tinggi (HOTS) meliputi kemam-puan logika dan penalaran (logic and reasoning), analisis (analysis), evaluasi (evaluation), dan kreasi (creation), pemecahan masalah (problem solving), dan pengambilan keputusan (judgement).

Kemampuan analisis dapat diartikan sebagai kemampuan individu untuk menentukan bagian-bagian dari suatu masalah dan menunjukkan hubungan antarbagian tersebut, melihat penyebab-penyebab dari suatu peristiwa atau memberi argumen-argumen yang menyokong suatu pernyataan (Sudrajat, 2011). Suherman memaparkan bahwa kemampuan evaluasi adalah kegiatan membuat penilaian berkenaan dengan nilai sebuah idea, kreasi, cara atau metode (Yudhanegara, 2012). Kemampuan kreasi 
adalah kemampuan untuk mengkombinasikan elemen-elemen untuk membentuk sebuah struktur yang baru dan unik, merancang cara, dan menemukan jawaban lebih dari satu (multiple solutions) (Brookhart, 2010, p. 55). Kemampuan penalaran ini diperlukan dalam proses berpikir dan menarik suatu kesimpulan yang berupa pengetahuan

Untuk mengetahui kemampuan berpikir tingkat tinggi seseorang, maka diperlukan indikator-indikator yang mampu mengukur kemampuan tersebut. Brookhart (2010) menyatakan indikator untuk mengukur kemampuan analisis ialah fokus pada ide utama, menganalisis argumen, serta membandingkan dan mengkontraskan. Indikator untuk mengukur kemampuan evaluasi ialah kemampuan mengambil keputusan atau metode agar sejalan dengan tujuan yang diinginkan. Indikator untuk mengukur kemampuan kreasi ialah menyelesaikan soal dengan solusi lebih dari satu, merancang suatu cara untuk menyelesaikan masalah, dan membuat sesuatu yang baru. Indikator kemampuan logika dan penalaran ialah konten, penalaran dan bukti, serta kejelaan gaya bahasa.

Untuk mewujudkan sumber daya manusia yang berkuaitas dan meningkatkan skor PISA Indonesia, maka diperlukan pembenahan dan pembaharuan pada aspek pendidikan. Untuk membenahi aspek pendidikan, langkah awal yang harus dilakukan ialah mengetahui dan mengenali kemampuan siswa secara menyeluruh dari semua disiplin ilmu, sehingga memudahkan pengembangan kemampuan siswa di dalam berbagai disiplin ilmu. Adapun mengenali kemampuan siswa secara menyeluruh mengandung arti mengenali kemampuan berpikir tingkat rendah (LOTS) dan kemampuan berpikir tingkat tinggi (HOTS) siswa. Beragamnya kemampuan tersebut mengharuskan digali secara langsung terhadap siswa dengan lingkup objek penelitian yang luas. Hal tersebut bertujuan mendapatkan data yang akurat dan mendetail.

Sehubungan dengan permasalahanpermasalahan yang telah dipaparkan, penelitian ini dilaksanakan dengan tujuan untuk mengetahui kemampuan berpikir tingkat tinggi siswa yang berumur 15 tahun dari hasil penyelesaian soal PISA yang diberikan. Hasil penelitian ini diharapkan dapat memberikan informasi tentang kemampuan berpikir tingkat tinggi siswa dalam disiplin ilmu matematika, sehingga dapat membantu mengembangkan kemampuan HOTS siswa guna memperbaiki level skor perolehan PISA dan dapat membantu memajukan kualitas matematika di Indonesia.

\section{Metode Penelitian}

Jenis penelitian ini adalah penelitian deskriptif dengan pendekatan kualitatif. Menurut (Sugiyono, 2010, p. 1), metode penelitian kualitatif adalah metode penelitian yang digunakan untuk meneliti pada kondisi objek yang alamiah. Analisis data bersifat induktif dan hasil penelitian lebih menekankan makna dari pada generalisasi. Makna adalah data yang sebenarnya, data yang pasti yang merupakan suatu nilai dibalik data yang tampak.

Pada penelitian ini dianalisis kemampuan berpikir tingkat tinggi (HOTS) siswa rentang usia 15 tahun di beberapa sekolah kabupaten Jember berbasis assessment logic and reasoning dan assessment analysis, evaluation, and creation dalam menyelesaikan soal PISA. Jadi, pendeskripsian dan pengkategorian tingkat kemamampuan berpikir tingkat tinggi merupakan sasaran utama penelitian ini. Untuk mencapai sasaran tersebut, diperlukan suatu prosedur penelitian. Adapun prosedur penelitian ini terdapat pada Gambar 1.

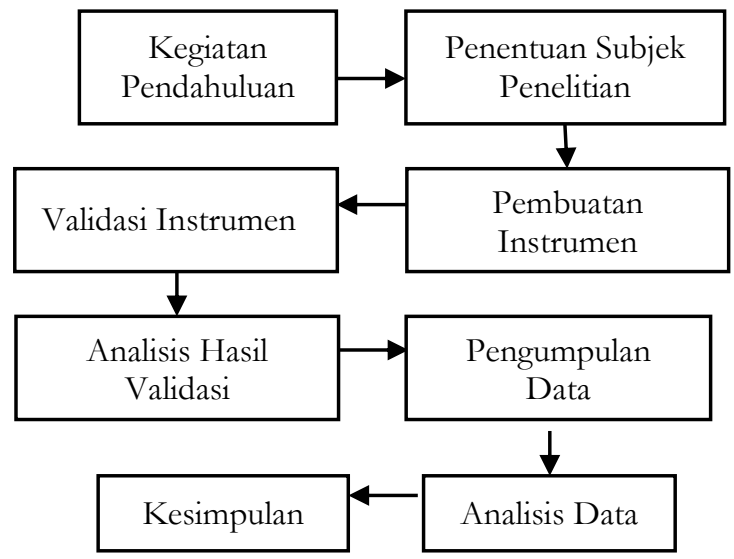

Gambar 1. Prosedur Penelitian 
Pada Gambar 1 dijelaskan bahwa tahap awal dalam penelitian ini yaitu tahap kegiatan pendahuluan. Tahap pendahuluan, peneliti menentukan daerah/tempat penelitian yang meliputi beberapa SMP di $\mathrm{Ka}$ bupaten Jember. Setelah tempat penelitian ditentukan, peneliti menentukan subjek penelitian. Subjek penelitian merupakan siswa SMP yang berusia 15 tahun sebanyak 30 siswa.

Suatu penelitian harus ada suatu instrumen penelitian yang telah valid. Sebelum peneliti melakukan penelitian, maka peneliti harus membuat instrumen penelitian. Instrumen tersebut meliputi rubrik penilaian, soal tes PISA, dan pedoman wawancara. Kemudian instrumen tersebut divalidasi kepada validator. Pada hasil uji validasi, peneliti melakukan analisis terhadap hasil tersebut untuk mengetahui tingkat kevalidannya.

Jika instrumen telah valid, maka instrumen tersebut dapat digunakan untuk tahap penelitian atau pengumpulan data. Pada tahap ini dilakukan dengan melakukan tes pada soal berstandar PISA untuk mengetahui kemampuan berpikir tingkat tinggi khusus untuk aspek kemampuan analisis, logika dan penalaran. Setelah tes tersebut dilakukan, pada akhirnya dilakukan wawancara terhadap siswa untuk memperoleh data dari aspek evaluasi dan kreasi siswa.

Tahap selanjutnya adalah analisis data. pada tahap ini hasil jawaban siswa dari soal tes PISA dan wawancara yang telah dilakukan akan dianalisis. Analisis ini bertujuan untuk mendeskripsikan kemampuan berpikir tingkat tinggi siswa berusia 15 tahun berbasis assessment logic and reasoning dan assessment analysis, evaluation, and creation. Setelah itu, melakukan pengkategorian level HOTS tinggi, sedang, dan rendah. Adapun langkahlangkah pengelompokannya sebagai berikut. Pertama, mencari nilai minimum dengan cara mengalikan banyak soal tes dengan skor terendah rubrik penilaian untuk kemampuan HOTS. Langkah kedua, mencari nilai maksimum dengan cara mengalikan banyak soal tes dengan skor tertinggi rubrik penilaian setiap kemampuan HOTS. Langkah ketiga, menentukan jangkauan data ter- sebut. Langkah terakhir, membagi jangkauan data menjadi 3 bagian, sehingga diperoleh interval kelas. Interval kelas terendah, sedang, dan tertinggi secara berurutan mencerminkan kategori siswa HOTS level rendah, sedang, dan tinggi.

\section{Hasil Penelitian dan Pembahasan}

Subjek penelitian yaitu siswa SMP berumur 15 tahun sebanyak 30 siswa yang tersebar di beberapa SMP di Kabupaten Jember. Selanjutnya, subjek penelitian tersebut mengikuti tes soal PISA dan wawancara pada waktu yang telah ditentukan. Hasil skor yang diperoleh dari jawaban tes soal PISA dan wawancara, digunakan dalam menentukan level kemampuan berpikir tingkat tinggi (Higher Order Thinking Skills/HOTS) siswa. Dari hasil tes dan wawancara HOTS siswa yang meliputi aspek logika dan penalaran, analisis, evaluasi, dan kreasi didapatkan skor skor tertinggi dan terendah secara berturut-turut adalah 146 dan 61. Dari skor tersebut dibuat kategorisasi tingkat kemampuan berpikir tingkat tinggi (HOTS) siswa yang disajikan pada Tabel 1.

Tabel 1. Kategorisasi Skor HOTS siswa

\begin{tabular}{ccc}
\hline No. & Skor & Kategori \\
\hline 1. & $50 \leq$ skor $<88$ & Rendah \\
2. & $88 \leq$ skor $<126$ & Sedang \\
3. & $126 \leq$ skor $<165$ & Tinggi \\
\hline
\end{tabular}

Adapun hasil penelitian yang didapat, dari 30 subjek penelitian didapatkan bahwa tidak ada siswa dengan HOTS tinggi, 18 siswa dengan HOTS sedang, dan 12 siswa dengan HOTS rendah. HOTS level sedang kurang mampu melakukan kemampuan analisis, evaluasi, kreasi, logika dan penalaran dengan baik untuk beberapa soal. HOTS level rendah tidak mampu melakukan kemampuan analisis, evaluasi, kreasi, logika dan penalaran dengan baik untuk semua soal.

Tes soal PISA yang diberikan ialah soal mirip PISA dalam bahasa Indonesia yang diadopsi dari tes PISA tahun 2012. Tes ini terdiri dari 5 butir soal. Berikut akan 
disajikan hasil pengerjaan beberapa siswa yang mewakili dalam kemampuan HOTS level sedang dan rendah.

\section{HOTS Level Sedang}

S101 merupakan kode pertama siswa berkemampuan HOTS level sedang. Adapun hasil pengerjaan siswa tersebut untuk soal nomor satu disajikan pada Gambar 2.

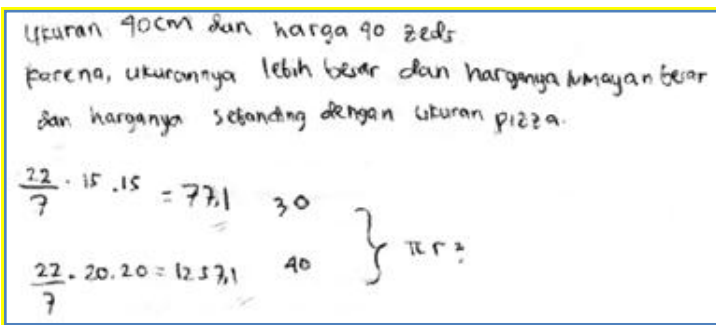

Gambar 2. Hasil Pengerjaan Soal Nomor 1 oleh Siswa S101

Soal nomor satu yang diujikan ialah soal uraian terbuka yang terbatas. Adapun materi soal tersebut terdiri dari konten matematika Change and Relationships, konteks Occupational, dan proses Formulate. Soal kontekstual ini mengharuskan siswa untuk mengubah dan mencari hubungan satu dengan yang lain, serta membuat formula untuk menemukan jawaban. Siswa berkemampuan HOTS level sedang mengerti tentang aplikasi aljabar dalam kehidupan sehari-hari. Berdasarkan hasil pengerjaan dan wawancara, siswa tersebut mampu mengidentifikasi hal yang diketahui dan ditanya. Pizza dengan diameter $30 \mathrm{~cm}$ dan $40 \mathrm{~cm}$ merupakan hal yang diketahui. Sedangkan pizza mana yang lebih murah merupakan hal yang ditanya. Siswa tersebut mampu merancang cara pengerjaan dengan mencari harga 1 $\mathrm{cm}^{2}$. Semakin murah harga $1 \mathrm{~cm}^{2}$, maka semakin hemat harga keseluruhan. Hal tersebut didasari atas analisis dasar kegunaan hal yang diketahui dalam menjawab soal. Perbedaan diameter memangurihi perbedaan pada luas pizza dan harga per $1 \mathrm{~cm}^{2}$. Pada konten jawaban, siswa memberikan penjelasan tentang hubungan antara luas pizza dengan harga, untuk mencari harga $1 \mathrm{~cm}^{2}$. Untuk mengetahui hal tersebut, maka harga pizza dibagi dengan luas pizza. Oleh karena
40/1257 lebih kecil dari 30/771, maka pizza yang paling murah ialah pizza dengan dimeter $40 \mathrm{~cm}$. Jawaban tersebut tepat, logis, dan teoretis. Selanjutnya, siswa dapat melakukan pengujian ulang dan mengkritisi jawaban dengan baik. Hal tersebut didasari oleh kemampuan analisis argumen yang baik pula, sebab setiap langkah pengerjaan didasari bukti dan alasan.

Adapun hasil pengerjaan siswa S101 untuk soal nomor dua disajikan pada Gambar 3.

$$
\begin{aligned}
& \frac{n}{0,80}=140 \quad \begin{array}{l}
n=140 \times 0,80 \\
=112 \\
\text { m per menit } \rightarrow \frac{112000}{3600}=31.1 \mathrm{~km} / \mathrm{jam}
\end{array} \\
& \text { Gambar 3. Hasil Pengerjaan Soal } \\
& \text { Nomor 2 oleh Siswa S101 }
\end{aligned}
$$

Soal nomor dua yang diujikan ialah soal uraian terbuka yang terbatas. Adapun materi soal tersebut terdiri dari konten matematika Change and Relationships, konteks Personal, dan proses Formulate. Soal kontekstual ini mengharuskan siswa untuk mengubah dan mencari hubungan satu dengan yang lain, serta membuat formula untuk menemukan jawaban. Siswa berkemampuan HOTS sedang kurang mengerti terhadap materi satuan dari variabel dan mengonversi ke dalam bentuk lain. Namun, siswa mampu menuliskan hal yang diketahui dan ditanya dari soal. Rumus langkah dan panjang langkah Bernard merupakan hal yang diketahui, sedangkan kecepatan Bernard merupakan hal yang ditanya. Siswa merancang cara pengerjaan dengan mengganggap nilai $n$ mencerminkan kecepatan dalam meter per menit. Selanjutnya, mengonversi satuan meter per menit ke dalam kilometer per jam dengan mengalikan 1000 kemudian membagi dengan 3600. Argumen tersebut tidaklah logis, sebab nilai $n$ ialah jumlah langkah per menit, dan mengonversi satuan satuan meter per menit ke dalam kilometer per jam dengan mengalikan $\frac{1}{1000}$ kemudian membagi dengan 3600. Oleh karena itu, siswa tidak mampu melakukan pengujian ulang, sebab 
sebagian besar langkah pengerjaan tidak didukung bukti dan alasan yang logis.

Adapun hasil pengerjaan siswa S101 untuk soal nomor tiga disajikan pada Gamber 4.

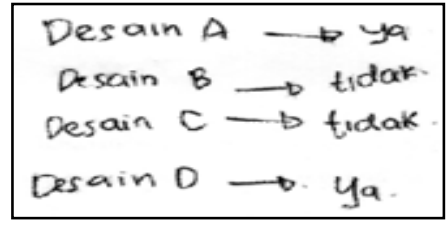

Gambar 4. Hasil Pengerjaan Soal Nomor 3 oleh Siswa S101

Soal nomor tiga yang diujikan ialah soal yang membutuhkan jawaban singkat. Adapun materi soal tersebut terdiri dari konten matematika Space and shape, konteks Occupational, dan proses Formulate. Soal kontekstual ini mengharuskan siswa untuk menguasai geometri, serta membuat formula untuk menemukan jawaban. Siswa berkemampuan HOTS level sedang kurang mengerti terhadap aplikasi keliling bangun datar dalam kehidupan sehari-hari. Untuk kemampuan mengidentifikasi ide utama, siswa mampu menuliskan hal yang diketahui dan ditanya dengan tepat. Empat buah desain pagar yang berbeda bentuk merupakan hal yang diketahui, sedangkan desain mana yang bisa dibuat dari $32 \mathrm{~m}$ kayu merupakan hal yang ditanya. Siswa tersebut merancang cara pengerjaan dengan menghitung keliling desain dan keindahan desain. Desain dengan keliling kurang atau sama dengan $32 \mathrm{~m}$, maka desain tersebut diterima. Oleh karena itu, jawaban akhir siswa ialah desain D. Selanjutnya, berdasarkan aspek keindahan desain A bagus dan indah, maka desain tersebut diterima. Argumen tersebut tidaklah logis, sebab untuk menentukan desain yang bisa dibuat dari $32 \mathrm{~m}$ kayu hanya ditentukan oleh keliling desain pagar saja. Alasan yang tidak logis tersebut mendorong siswa kurang mampu melakukan pengujian ulang serta mengkritisi langkah pengerjaan.

Adapun hasil pengerjaan siswa S101 untuk soal nomor empat disajikan pada Gambar 5. Soal nomor empat yang diujikan ialah soal uraian terbuka yabg terbatas. Adapun materi soal tersebut terdiri dari konten matematika Change and Relationships, konteks Societal, dan proses Formulate. Soal kontekstual ini mengharuskan siswa untuk mengubah dan mecari hubungan satu dengan yang lain, serta membuat formula untuk menemukan jawaban. Siswa berkemampuan HOTS level sedang mengerti tentang aplikasi materi gerak lurus beraturan. Siswa mampu menuliskan hal yang diketahui dan ditanya dengan tepat. Kecepatan mendaki, kecepatan turun, serta panjang lintasan pendakian dan turun merupakan hal yang diketahui. Sedangkan pukul berapa Toshi harus berangkat agar kembali tepat pada pukul 20.00 merupakan hal yang ditanya. Siswa merancang cara pengerjaan dengan mencari waktu yang diperlukan untuk mendaki dan turun dengan menggunakan formula $\mathrm{v}=\mathrm{s} / \mathrm{t}$. Kemudian, menganggap pukul Toshi harus berangkat dengan mengurangkan waktu total perjalanan dengan jam harus kembali. Argumen tersebut terbalik, seharusnya jam harus kembali dikurangi dengan waktu total perjalanan. Hal tersebut mempengaruhi pada kurang mampunya siswa dalam melakukan pengujian ulang.

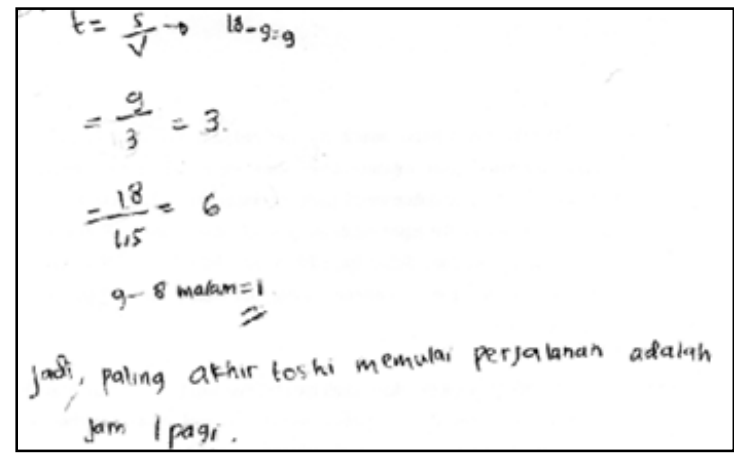

Gambar 5. Hasil Pengerjaan Soal

Nomor 4 oleh Siswa S101

Adapun hasil pengerjaan siswa S101 untuk soal nomor lima disajikan pada Gambar 6. Soal nomor lima yang diujikan ialah soal yang memerlukan jawaban singkat. Adapun materi soal tersebut terdiri dari konten matematika Quantity, konteks Personal, dan proses Formulate. Soal kontekstual ini mengharuskan siswa memahami terhadap hubungan bilangan dan pola bilangan, serta membuat formula untuk menemukan jawaban. Siswa berkemampuan HOTS level 
sedang mengerti terhadap aplikasi perbandingan senilai dalam kehidupan sehari-hari. Siswa tersebut mampu menuliskan hal yang diketahui dan ditanya soal dengan tepat. Komposisi bahan-bahan untuk membuat saus salad $100 \mathrm{~mL}$ merupakan hal yang ditanya, sedangkan berapa $\mathrm{mL}$ minyak salad yang dibutuhkan untuk membuat $150 \mathrm{~mL}$ saus salad merupakan hal yang ditanya. Siswa merancang cara pengerjaan dengan menggunakan perbandingan senilai. Untuk membuat saus salad $100 \mathrm{~mL}$ membutuhkan $60 \mathrm{~mL}$, maka untuk membuat saus salad $150 \mathrm{~mL}$ membutuhkan $90 \mathrm{~mL}$. Argumen tersebut logis dan teoretis, sehingga mendorong siswa mampu melakukan pengujian ulang dan mengkritisi langkah pengerjaan.

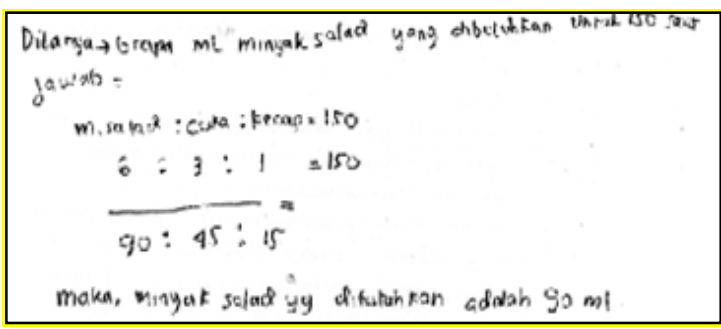

Gambar 6. Hasil Pengerjaan Soal Nomor 5 oleh Siswa S101

S102 merupakan kode kedua siswa berkemampuan HOTS level sedang. Adapun hasil pengerjaan siswa tersebut untuk soal nomor satu disajikan pada Gambar 7.

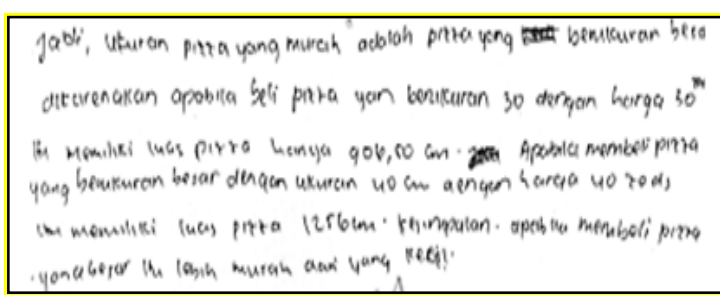

Gambar 7. Hasil Pengerjaan Soal Nomor 1 oleh Siswa S102

Siswa berkemampuan HOTS level sedang mengerti tentang aplikasi aljabar dalam kehidupan sehari-hari. Berdasarkan hasil pengerjaan dan wawancara, siswa tersebut mampu mengidentifikasi hal yang diketahui dan ditanya. Pizza dengan diameter $30 \mathrm{~cm}$ dan $40 \mathrm{~cm}$ merupakan hal yang diketahui, sedangkan pizza mana yang lebih murah merupakan hal yang ditanya. Siswa tersebut mampu merancang cara pengerjaan dengan mencari harga $1 \mathrm{~cm}^{2}$. Semakin murah harga $1 \mathrm{~cm}^{2}$, maka semakin hemat harga keseluruhan. Hal tersebut didasari atas analisis dasar kegunaan hal yang diketahui dalam menjawab soal. Perbedaan diameter memengaruhi perbedaan pada luas pizza dan harga per $1 \mathrm{~cm}^{2}$. Pada konten jawaban, siswa memberikan penjelasan tentang hubungan antara luas pizza dengan harga, untuk mencari harga $1 \mathrm{~cm}^{2}$. Untuk mengetahui hal tersebut, maka harga pizza dibagi dengan luas pizza. Oleh karena 40/1257 lebih kecil dari 30/771, maka pizza yang paling murah ialah pizza dengan diameter $40 \mathrm{~cm}$. Jawaban tersebut tepat, logis, dan teoretis. Selanjutnya, siswa dapat melakukan pengujian ulang dan mengkritisi jawaban dengan baik. Hal tersebut didasari oleh kemampuan analisis argumen yang baik pula, sebab setiap langkah pengerjaan didasari bukti dan alasan.

Adapun hasil pengerjaan siswa S102 untuk soal nomor dua disajikan pada Gambar 8.

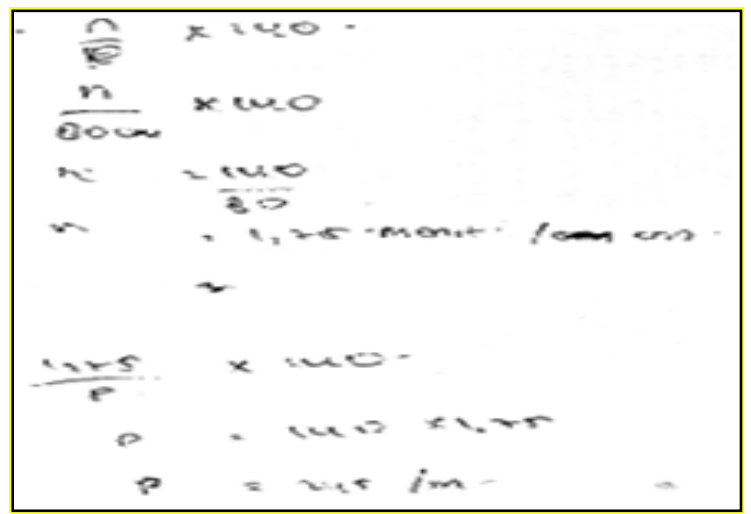

Gambar 8. Hasil Pengerjaan Soal Nomor 2 oleh Siswa S102

Siswa berkemampuan HOTS sedang kurang mengerti terhadap materi satuan dari variabel dan mengonversi ke dalam bentuk lain. Namun, siswa mampu menuliskan hal yang diketahui dan ditanya dari soal. Rumus langkah dan panjang langkah Bernard merupakan hal yang diketahui, sedangkan kecepatan Bernard merupakan hal yang ditanya. Siswa merancang cara pengerjaan dengan mengganggap nilai $n$ mencerminkan kecepatan dalam meter per menit. Argumen tersebut tidaklah logis, sebab nilai $n$ ialah jum- 
lah langkah per menit, dan mengonversi satuan satuan meter per menit ke dalam kilometer per jam dengan mengalikan $\frac{1}{1000}$ kemudian membagi dengan 3600. Oleh karena itu, siswa tidak mampu melakukan pengujian ulang, sebab sebagian besar langkah pengerjaan tidak didukung bukti dan alasan yang logis.

Adapun hasil pengerjaan siswa S102 untuk soal nomor tiga disajikan pada Gambar 9.

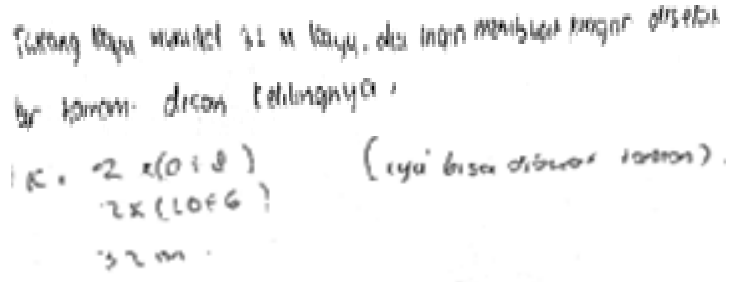

Gambar 9. Hasil Pengerjaan Soal

Nomor 3 oleh Siswa S102

Siswa berkemampuan HOTS level sedang mengerti terhadap aplikasi keliling bangun datar dalam kehidupan sehari-hari. Untuk kemampuan mengidentifikasi ide utama, siswa mampu menuliskan hal yang diketahui dan ditanya dengan tepat. Empat buah desain pagar yang berbeda bentuk merupakan hal yang diketahui, sedangkan desain mana yang bisa dibuat dari $32 \mathrm{~m}$ kayu merupakan hal yang ditanya. Siswa tersebut merancang cara pengerjaan dengan menghitung keliling desain. Desain dengan keliling kurang atau sama dengan $32 \mathrm{~m}$, maka desain tersebut diterima. Oleh karena itu, jawaban akhir siswa ialah desain D. Argumen tersebut logi dan teoretis. Oleh karena itu siswa mampu melakukan pengujian ulang dan mengkritisi langkah pengerjaan.

Adapun hasil pengerjaan siswa S102 untuk soal nomor empat disajikan pada Gambar 10.

Siswa berkemampuan HOTS level sedang kurang mengerti tentang aplikasi materi gerak lurus beraturan. Namun, siswa mampu menuliskan hal yang diketahui dan ditanya dengan tepat. Kecepatan daki, kecepatan turun, serta panjang lintasan daki dan turun merupakan hal yang diketahui, sedangkan pukul berapa Toshi harus berang- kat agar kembali tepat pada pukul 20.00 merupakan hal yang ditanya. Siswa tidak merancang cara pengerjaan dikarenakan kebingungan terhadap soal dan kegunaan hal yang diketahui. Jawaban siswa yang menunjukkan pukul 14.00 Toshi harus berangkat merupakan hasil menduga-duga tanpa disertai alasan logis. Oleh karena itu, siswa tidak mampu melakukan pengujian ulang serta mengkritisi langkah pengerjaan.

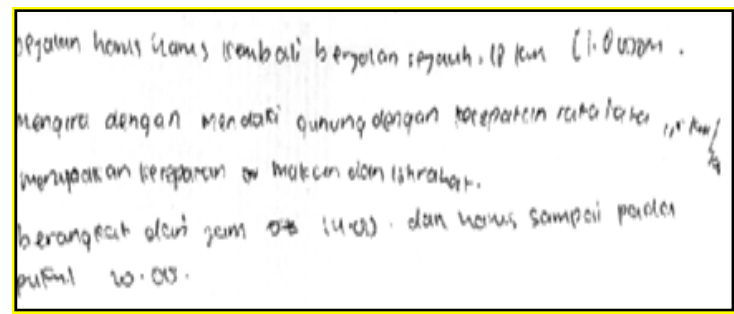

Gambar 10. Hasil Pengerjaan Soal Nomor 4 oleh Siswa S102

Adapun hasil pengerjaan siswa S102 untuk soal nomor lima sebagai berikut.

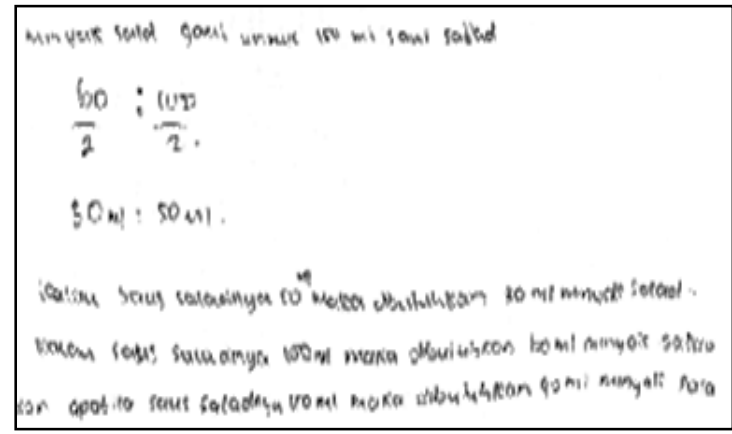

Gambar 11. Hasil Pengerjaan Soal Nomor 5 oleh Siswa S102

Siswa berkemampuan HOTS level sedang mengerti terhadap aplikasi perbandingan senilai dalam kehidupan sehari-hari. Siswa tersebut mampu menuliskan hal yang diketahui dan ditanya soal dengan tepat. Komposisi bahan-bahan untuk membuat saus salad $100 \mathrm{~mL}$ merupakan hal yang ditanya, sedangkan berapa $\mathrm{mL}$ minyak salad yang dibutuhkan untuk membuat $150 \mathrm{~mL}$ saus salad merupakan hal yang ditanya. Siswa merancang cara pengerjaan dengan menggunakan perbandingan senilai. Untuk membuat saus salad $100 \mathrm{~mL}$ membutuhkan $60 \mathrm{~mL}$, maka untuk membuat saus salad $150 \mathrm{~mL}$ membutuhkan $90 \mathrm{~mL}$. Argumen

Kemampuan Berpikir Tingkat Tinggi Siswa SMP ... - 149

Dian Kurniati, Romi Harimukti, Nur Asiyah Jamil 
tersebut logis dan teoretis, sehingga mendorong siswa mampu melakukan pengujian ulang dan mengkritisi langkah pengerjaan.

\section{HOTS Level Rendah}

S201 merupakan kode subjek penelitian pertama siswa berkemampuan HOTS rendah. Berikut ini merupakan hasil pengerjaan siswa S201 dalam menyelesaikan soal nomor satu.

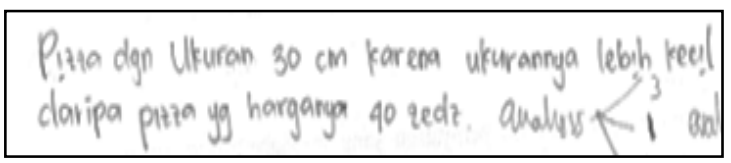

Gambar 12. Hasil Pengerjaan Soal

Nomor 1 oleh Siswa S201

Siswa berkemampuan HOTS level rendah kurang mengerti tentang aplikasi aljabar dalam kehidupan sehari-hari. Berdasarkan hasil pengerjaan dan wawancara, siswa tersebut mampu mengidentifikasi hal yang diketahui dan ditanya. Pizza dengan diameter $30 \mathrm{~cm}$ dan $40 \mathrm{~cm}$ merupakan hal yang diketahui, sedangkan pizza mana yang lebih murah merupakan hal yang ditanya. Siswa tersebut mampu merancang cara pengerjaan dengan menbandingkan harga pizza berdiameter $30 \mathrm{~cm}$ dengan $40 \mathrm{~cm}$. Oleh karena itu, siswa menjawab pizza berdiameter $30 \mathrm{~cm}$ lebih murah, dikarenakan 30 zeds lebih kecil dari 40 zeds. Jawaban tersebut tidak tepat dan logis, dikarenakan ada hubungan antara harga dan luas pizza. Siswa hanya menduga-duga tanpa disertai alasan logis. Oleh karena itu, siswa tidak mampu melakukan pengujian ulang dan mengkritisi jawaban.

Adapun hasil pengerjaan siswa S201 untuk soal nomor dua disajikan pada Gambar 12.

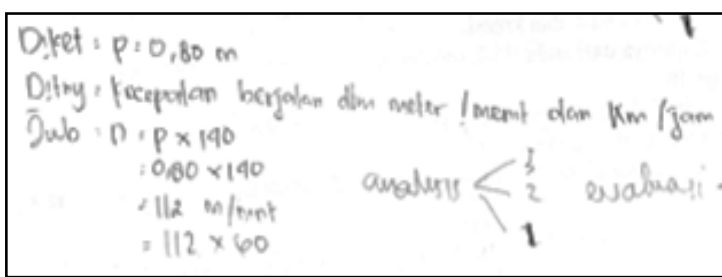

Gambar 13. Hasil Pengerjaan Soal Nomor 2 oleh Siswa S201
Siswa berkemampuan HOTS rendah kurang mengerti terhadap materi satuan dari variabel dan mengonversi ke dalam bentuk lain. Namun siswa mampu menuliskan hal yang diketahui dan ditanya dari soal. Rumus langkah dan panjang langkah Bernard merupakan hal yang diketahui, sedangkan kecepatan Bernard merupakan hal yang ditanya. Siswa merancang cara pengerjaan dengan mengganggap nilai $n$ mencerminkan kecepatan dalam meter per menit. Sehingga didapat jawaban siswa $112 \mathrm{~m} /$ menit. Argumen tersebut tidaklah logis, sebab nilai $n$ ialah jumlah langkah per menit, dan mengonversi satuan satuan meter per menit ke dalam kilometer per jam dengan mengalikan $\frac{1}{1000}$ kemudian membagi dengan 3600. Oleh karena itu, siswa tidak mampu melakukan pengujian ulang, sebab sebagian besar langkah pengerjaan tidak didukung bukti dan alasan yang logis.

Adapun hasil pengerjaan siswa S201 untuk soal nomor tiga disajikan pada Gambar 14.

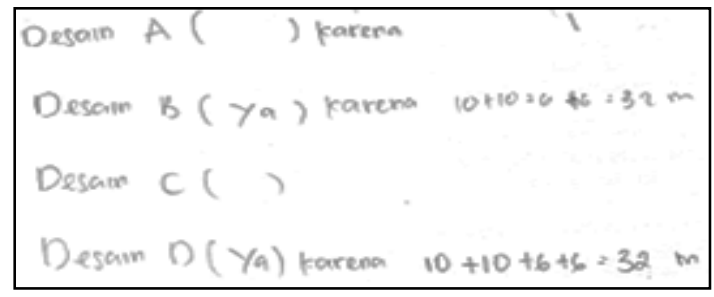

Gambar 14. Hasil Pengerjaan Soal Nomor 3 oleh Siswa S201

Siswa berkemampuan HOTS level rendah kurang mengerti terhadap aplikasi keliling bangun datar dalam kehidupan sehari-hari. Untuk kemampuan mengidentifikasi ide utama, siswa mampu menuliskan hal yang diketahui dan ditanya dengan tepat. Empat buah desain pagar yang berbeda bentuk merupakan hal yang diketahui, sedangkan desain mana yang bisa dibuat dari $32 \mathrm{~m}$ kayu merupakan hal yang ditanya. Siswa tersebut merancang cara pengerjaan dengan menghitung keliling desain. Desain dengan keliling kurang atau sama dengan 32 $\mathrm{m}$, maka desain tersebut diterima. Oleh karena itu, jawaban akhir siswa ialah desain B dan D. Argumen tersebut tidak logis 
untuk desain B, sebab desain B berbentuk jajaran genjang dengan keliling lebih dari 32 $\mathrm{m}$. Oleh karena, itu siswa kurang mampu melakukan pengujian ulang dan mengkritisi langkah pengerjaan.

Adapun hasil pengerjaan siswa S201 untuk soal nomor empat disajikan pada Gambar 15

$$
\text { Pada jam og.30 pagi }
$$

Gambar 15. Hasil Pengerjaan Soal

Nomor 4 oleh Siswa S201

Siswa berkemampuan HOTS level rendah kurang mengerti tentang aplikasi materi gerak lurus beraturan. Siswa mampu menuliskan hal yang diketahui dan ditanya dengan tepat. Kecepatan daki, kecepatan turun, serta panjang lintasan daki dan turun merupakan hal yang diketahui, sedangkan pukul berapa Toshi harus berangkat agar kembali tepat pada pukul 20.00 merupakan hal yang ditanya. Siswa tidak merancang cara pengerjaan dikarenakan kebingungan terhadap soal dan kegunaan hal yang diketahui. Jawaban siswa yang menunjukkan pukul 09.30 Toshi harus berangkat merupakan hasil menduga-duga tanpa disertai alasan logis. Oleh karena itu, siswa tidak mampu melakukan pengujian ulang serta mengkritisi langkah pengerjaan.

Adapun hasil pengerjaan siswa S201 untuk soal nomor lima disajikan pada Gambar 16.

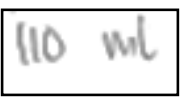

\section{Gambar 16. Hasil Pengerjaan Soal}

Nomor 5 oleh Siswa S201

Siswa berkemampuan HOTS level rendah kurang mengerti terhadap aplikasi perbandingan senilai dalam kehidupan sehari-hari. Siswa tersebut mampu menuliskan hal yang diketahui dan ditanya soal dengan tepat. Komposisi bahan-bahan untuk membuat saus salad $100 \mathrm{~mL}$ merupakan hal yang ditanya, sedangkan berapa $\mathrm{mL}$ minyak salad yang dibutuhkan untuk membuat $150 \mathrm{~mL}$ saus salad merupakan hal yang ditanya. Sis- wa tidak merancang cara dikarenakan kebingungan terhadap soal dan kegunaan hal yang diketahui. Jawaban siswa yang menunjukkan $110 \mathrm{~mL}$ minyak salad yan dibutuhkan merupakan hasil menduga-duga tanpa disertai alasan logis. Oleh karena itu, siswa tidak mampu melakukan pengujian ulang serta mengkritisi langkah pengerjaan.

S202 merupakan kode subjek penelitian kedua siswa berkemampuan HOTS rendah. Berikut ini merupakan hasil pengerjaan siswa S202 dalam menyelesaikan soal nomor satu.

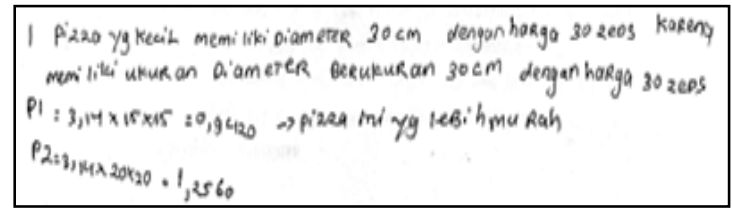

Gambar 17. Hasil Pengerjaan Soal Nomor 1 oleh Siswa S202

Siswa berkemampuan HOTS level rendah kurang mengerti tentang aplikasi aljabar dalam kehidupan sehari-hari. Berdasarkan hasil pengerjaan dan wawancara, siswa tersebut mampu mengidentifikasi hal yang diketahui dan ditanya. Pizza dengan diameter $30 \mathrm{~cm}$ dan $40 \mathrm{~cm}$ merupakan hal yang diketahui, sedangkan pizza mana yang lebih murah merupakan hal yang ditanya. Siswa tersebut mampu merancang cara pengerjaan dengan menbandingkan harga pizza berdiameter $30 \mathrm{~cm}$ dengan $40 \mathrm{~cm}$. Oleh karena itu, siswa menjawab pizza berdiameter $30 \mathrm{~cm}$ lebih murah, dikarenakan 30 zeds lebih kecil dari 40 zeds. Jawaban tersebut tidak tepat dan logis, dikarenakan ada hubungan antara harga dan luas pizza. Siswa hanya menduga-duga tanpa disertai alasan logis. Oleh karena itu, siswa tidak mampu melakukan pengujian ulang dan mengkritisi jawaban.

Adapun hasil pengerjaan siswa S202 untuk soal nomor dua disajikan pada Gambar 18.

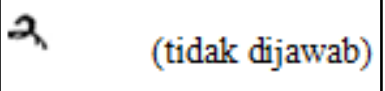

Gambar 18. Hasil Pengerjaan Soal Nomor 2 oleh Siswa S202 
Siswa berkemampuan HOTS rendah tidak mengerti terhadap materi satuan dari variabel dan mengonversi ke dalam bentuk lain. Namun, siswa mampu menuliskan hal yang diketahui dan ditanya dari soal. Rumus langkah dan panjang langkah Bernard merupakan hal yang diketahui, sedangkan kecepatan Bernard merupakan hal yang ditanya. Siswa tidak merancang cara pengerjaan dan menjawab soal dikarenakan kebingungan terhadap soal dan kegunaan hal yang diketahui.

Adapun hasil pengerjaan siswa S202 untuk soal nomor tiga disajikan pada Gambar 19.

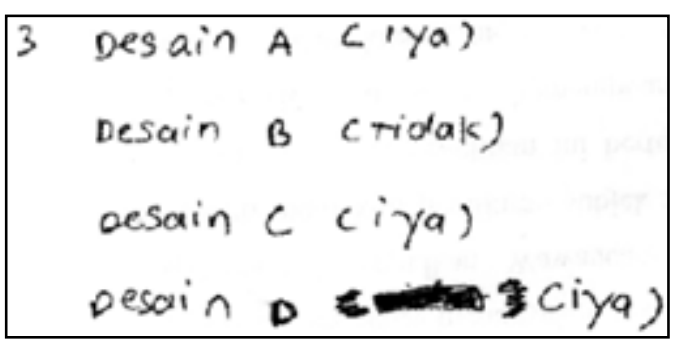

Gambar 19. Hasil Pengerjaan Soal Nomor 3 oleh Siswa S202

Siswa berkemampuan HOTS level rendah kurang mengerti terhadap aplikasi keliling bangun datar dalam kehidupan sehari-hari. Untuk kemampuan mengidentifikasi ide utama, siswa mampu menuliskan hal yang diketahui dan ditanya dengan tepat. Empat buah desain pagar yang berbeda bentuk merupakan hal yang diketahui, sedangkan desain mana yang bisa dibuat dari $32 \mathrm{~m}$ kayu merupakan hal yang ditanya. Siswa tersebut merancang cara pengerjaan dengan menghitung keliling desain dan keindahan desain. Desain dengan keliling kurang atau sama dengan $32 \mathrm{~m}$, maka desain tersebut diterima. Oleh karena itu, jawaban akhir siswa ialah desain D. Selanjutnya, berdasarkan aspek keindahan desain A dan $\mathrm{C}$ bagus dan indah, maka desain tersebut diterima. Argumen tersebut tidaklah logis, sebab untuk menentukan desain yang bisa dibuat dari $32 \mathrm{~m}$ kayu hanya ditentukan oleh keliling desain pagar saja. Alasan yang tidak logis tersebut mendorong siswa kurang mampu melakukan pengujian ulang serta mengkritisi langkah pengerjaan.
Adapun hasil pengerjaan siswa S202 untuk soal nomor empat disajikan pada Gambar 20.

$$
49+9=10
$$

Gambar 20. Hasil Pengerjaan Soal
Nomor 4 oleh Siswa S202

Siswa berkemampuan HOTS level sedang mengerti tentang aplikasi materi gerak lurus beraturan. Siswa mampu menuliskan hal yang diketahui dan ditanya dengan tepat. Kecepatan daki, kecepatan turun, serta panjang lintasan daki dan turun merupakan hal yang diketahui, sedangkan pukul berapa Toshi harus berangkat agar kembali tepat pada pukul 20.00 merupakan hal yang ditanya. Siswa tidak mampu menjawab dan hanya menuliskan panjang lintasan keseluruhan yakni $18 \mathrm{~km}$.

Adapun hasil pengerjaan siswa S202 untuk soal nomor lima disajikan pada Gambar 21.

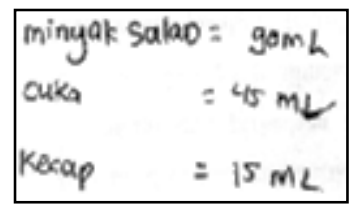

Gambar 21. Hasil Pengerjaan Soal Nomor 4 oleh Siswa S202

Siswa berkemampuan HOTS level rendah mengerti terhadap aplikasi perbandingan senilai dalam kehidupan sehari-hari. Siswa tersebut mampu menuliskan hal yang diketahui dan ditanya soal dengan tepat. Komposisi bahan-bahan untuk membuat saus salad $100 \mathrm{~mL}$ merupakan hal yang ditanya, sedangkan berapa $\mathrm{mL}$ minyak salad yang dibutuhkan untuk membuat $150 \mathrm{~mL}$ saus salad merupakan hal yang ditanya. Siswa merancang cara pengerjaan dengan menggunakan perbandingan senilai. Untuk membuat saus salad $100 \mathrm{~mL}$ membutuhkan $60 \mathrm{~mL}$, maka untuk membuat saus salad $150 \mathrm{~mL}$ membutuhkan $90 \mathrm{~mL}$. Argumen tersebut logis dan teoretis, sehingga mendorong siswa mampu melakukan pengujian ulang dan mengkritisi langkah pengerjaan. 
Berdasarkan hasil pengerjaan siswa di atas dapat diketahui kecenderungan kemampuan berpikir tingkat tinggi siswa. Kemampuan analisis berkaitan dengan kemampuan identifikasi ide utama soal, menganalisis argumen, serta membandingkan dan mengontraskan hal yang diketahui. Siswa berlevel HOTS sedang mampu mengidentifikasi ide utama dengan menyatakan hal yang diketahui dan ditanya pada soal dengan jelas, ringkas, dan tepat untuk semua soal. Selanjutnya, siswa tersebut memberikan alasan teoretis dalam setiap langkah pengerjaan hingga jawaban akhir dengan tepat untuk beberapa soal. Siswa tersebut juga mampu memberikan persamaan, perbedaan, serta kegunaan hal yang diketahui untuk menjawab soal dengan tepat untuk beberapa soal. Siswa berlevel HOTS rendah mampu mengidentifikasi ide utama dengan menyatakan hal yang diketahui dan ditanya pada soal dengan tepat untuk semua soal. $\mathrm{Na}$ mun, siswa tersebut tidak mampu memberikan alasan teoretis dalam setiap langkah pengerjaan hingga jawaban akhir untuk semua soal. Siswa tersebut juga tidak mampu memberikan persamaan, perbedaan, serta kegunaan hal yang diketahui untuk menjawab soal untuk semua soal yang diberikan.

Kemampuan evaluasi berkaitan dengan kemampuan memberikan penilaian terhadap solusi dan metode yang digunakan dalam menjawab soal, dan mengkritisi argumen. Siswa berlevel HOTS sedang mampu memberikan penilaian terhadap solusi dan metode yang digunakan dalam menjawab soal dengan tepat untuk beberapa soal. Siswa tersebut yakin dengan jawaban dan cara yang digunakan dalam menjawab beberapa soal. Hal tersebut didasarkan pada logis dan teoretis jawaban dan cara yang digunakan. Selanjutnya, siswa tersebut mampu mengritisi argumen dengan tepat untuk beberapa soal. Siswa melakukan pengecekan ulang mulai dari hal yang diketahui hingga kesimpulan jawaban dengan memperhatikan aspek teoretis langkah pengerjaan dengan tepat untuk beberapa soal. Siswa berlevel HOTS rendah tidak mampu memberikan penilaian terhadap solusi dan metode yang digunakan dalam menjawab soal dengan tepat untuk semua soal. Siswa tersebut tidak yakin dengan jawaban dan cara yang digunakan dalam menjawab soal. Selanjutnya, siswa tersebut tidak mampu mengkritisi argumen dengan tepat untuk semua soal. Siswa tidak melakukan pengecekan ulang tidak mengerti terhadap langkah pengerjaan.

Kemampuan kreasi berkaitan dengan kemampuan merancang cara pengerjaan soal dan membuat langkah pengerjaan baru. Siswa berlevel HOTS sedang mampu merancang cara pengerjaan untuk menjawab beberapa soal dengan tepat. Siswa terbut merancang cara dengan mempertimbangkan analisis awal pada hal yang diketahui dan ditanya pada soal, sehingga diperoleh cara pengerjaan yang tepat. Selanjutnya, siswa tersebut mampu membuat langkah pengerjaan baru dengan memadukan langkah-langkah pengerjaan sebelumnya secara logis dan teoretis untuk beberapa soal. Siswa berlevel HOTS rendah tidak mampu merancang cara pengerjaan untuk menjawab semua soal dengan tepat. Siswa tersebut tidak mampu mempertimbangkan analisis awal pada hal yang diketahui dan ditanya pada soal, serta kegunaanya dalam menjawab soal. Selanjutnya, siswa tersebut tidak mampu membuat langkah pengerjaan baru dengan memadukan langkah-langkah pengerjaan sebelumnya secara logis dan teoretis untuk semua soal. Hal tersebut dikarenakan kebingungan pada semua langkah pengerjaan.

Kemampuan logika dan penalaran meliputi konten jawaban, penalaran dan bukti, serta kejelasan gaya bahasa. Siswa berlevel HOTS sedang, konten/isi jawaban terdapat langkah pengerjaan yang lengkap, sistematis, dan teoretis untuk jawaban beberapa soal. Selanjutnya, siswa tersebut memberikan alasan pengerjaan dengan logis dan tulisan jawaban jelas serta efektif. Siswa berlevel HOTS rendah, konten/isi jawaban tidak terdapat langkah pengerjaan yang lengkap, sistematis, dan teoretis untuk jawaban semua soal. Selanjutnya, siswa tersebut tidak memberikan alasan pengerjaan dengan logis dan tulisan jawaban jelas serta efektif. 
Pada penelitian ini dapat diketahui adanya keterkaitan antara kemampuan kreasi dengan kemampuan analisis dan evaluasi. Kemampuan kreasi tidak akan mampu berdiri sendiri, dalam artian kemampuan kreasi dipengaruhi kemampuan analisis dan evaluasi siswa. Siswa berkemampuan analisis dan evaluasi sedang, mengakibatkan kemampuan kreasi siswa berlevel sedang pula. Hal tersebut juga berlaku pada siswa yang berkemampuan analisis dan evaluasi rendah, mereka cenderung berkemampuan kreasi rendah pula. Hasil penelitian di atas relevan dengan teori yang menyatakan syarat siswa mampu melakukan kreasi, jika ia telah mampu melakukan analisis dan evaluasi terlebih dahulu.

\section{Simpulan}

Berdasarkan hasil analisis dan pembahasan berkaitan dengan kemampuan berpikir tingkat tinggi (HOTS) siswa, dapat diambil beberapa kesimpulan sebagai berikut.

Pertama, siswa berkemampuan HOTS level sedang mampu mengidentifikasi ide utama, menganalisis argumen, dan menunjukkan kegunaan hal yang diketahui untuk menjawab beberapa soal, sehingga memiliki kemampuan analisis cukup baik. Siswa tersebut juga mampu memberikan penilaian terhadap solusi dan metode yang digunakan serta melakukan pengujian ulang untuk beberapa soal, sehingga memiliki kemampuan evaluasi cukup baik. Siswa tersebut juga mampu merancang cara pengerjaan dan menunjukkan jawaban benar untuk beberapa soal, sehingga memiliki kemampuan kreasi cukup baik. Pada kemampuan logika dan penalaran, siswa menuliskan konten jawaban, bukti serta alasan, dan kejelasan gaya bahasa dengan efektif, baik, dan logis dalam menyelesaikan beberapa soal tes PISA.

Kedua, siswa berkemampuan HOTS level rendah kurang mampu mengidentifikasi ide utama, menganalisa argumen, dan menunjukkan kegunaan hal yang diketahui untuk menjawab semua soal, sehingga memiliki kemampuan analisis kurang baik. Siswa tersebut juga kurang mampu memberikan penilaian terhadap solusi dan metode yang digunakan serta melakukan pengujian ulang untuk semua soal, sehingga memiliki kemampuan evaluasi kurang baik. Siswa tersebut juga kurang mampu merancang cara pengerjaan dan menunjukkan jawaban benar untuk semua soal, sehingga memiliki kemampuan kreasi kurang baik. Pada kemampuan logika dan penalaran, siswa tidak mampu menuliskan konten jawaban, bukti serta alasan, dan kejelasan gaya bahasa dengan efektif, baik, dan logis dalam menyelesaikan semua soal tes PISA.

Ketiga, tidak adanya siswa berkemampuan HOTS tinggi disebabkan kurang mengerti terhadap beberapa materi dan kegunaannya dalam kehidupan sehari-hari. Keempat, adanya hubungan hierarki antara kemampuan analisis, evaluasi, dan kreasi;

Adapun saran bagi peneliti lanjut, penelitian ini dapat dijadikan masukan untuk melakukan penelitian sejenis baik dalam mengembangkan instrumen untuk meningkatkan kemampuan HOTS siswa, maupun menganalisa faktor-faktor yang mempengaruhi kemampuan tersebut. Selain itu, agar lebih valid dalam mengukur kemampuan HOTS siswa, hendaknya dilakukan uji reliabelitas pada soal terjemah tes PISA.

\section{Daftar Pusaka}

Brookhart, S. M. (2010). How to assess higherorder thinking skills in your classroom. Alexandria: ASCD.

Istiyono, E., Mardapi, D., \& Suparno. (2014). Pengembangan tes kemampuan berpikir tingkat tinggi fisika (PysTHOTS) peserta didik sma. Jurnal Penelitian Dan Evaluasi Pendidikan, 18(1), 1-12. Retrieved from http://dx.doi.org/10.21831/pep.v18i1 .2120

Lewy, Zulkardi, \& Aisyah, N. (2009). Pengembangan soal untuk mengukur kemampuan berpikir tingkat tinggi pokok bahasan barisan dan deret bilangan di kelas IX akselerasi SMP Xaverius Maria Palembang. Jurnal Pendidikan Matematika, 3(2). Retrieved from 
http://ejournal.unsri.ac.id/index.php/ jpm/article/view/326/89

OECD. (2013). PIS A 2012 assessment and analytical framework: mathematics, reading, science, problem solving and financial literacy. German: OECD Publishing.

OECD. (2014). PIS A 2012 results in focus: What 15 year olds know and what they can do with what they know. German: OECD Publishing.

Setiawan, H. (2014). Soal matematika dalam PISA kaitannya dengan literasi matematika dan keterampilan berpikir tingkat tinggi. In Prosiding Seminar Nasional Matematika, Universitas Jember.

Sudrajat, A. (2011). Kemampuan menganalisis dalam pembelajaran. Retrieved October 27, 2015, from https://akhmadsudrajat.wordpress.co $\mathrm{m} / 2011 / 05 / 08 /$ kemampuanmenganalisis-dalam-pembelajaran/

Sugiyono. (2010). Memahami penelitian kualitatif. Bandung: CV. Alfabeta.

Wardhani, S. (2015). Pembelajaran dan penilaian aspek pemahaman konsep, penalaran dan komunikasi, pemecahan masalah. Retrieved April 23, 2015, from

http://p4tkmatematika.org/file/PRO

DUK/PAKET

FASILITASI/SMP/Standar Penilaian Pendidikan.pdf

Yudhanegara, M. R. (2012). Taksonomi bloom. Retrieved October 27, 2015, from http:// mridwanyudhanegara.blogspot. co.id/2012/03/taksonomi-bloom.html 